chromatography or in these improved techniques, the substances form either rings or ares ; that is, elongation takes place at right angles to the direction of flow of solvent. This helps to increase the distance of separation between substances of close $R_{F}$ values and therefore results in improved separations.

I wish to thank Dr. S. C. Roy, of this College, for his interest, and Dr. D. P. Burma, Bose Research Institute, Calcutta, for helpful criticism.

N. C. Ganguli

Department of Applied Chemistry,

University College of Science and Technology, Calcutta 9. March 18.

${ }^{1}$ Matthias, W., Naturwiss., 41, 17 (1954).

2 Ganguli, N. C., Seience and Culture, [19, 460 (1954)].

\section{Staining of Bound Lipids}

Methods at present used for staining bound lipids either give an inadequate result histologically or depend on chemical reactions not characteristic of lipids as a class.

It has been found that if paraffin sections of variously fixed tissues are washed in water for several hours, and then rinsed in alcohol, they are well stained by 2 per cent sudan black $B$ in acetone at $37^{\circ} \mathrm{C}$. Staining is carried out in an airtight container, is progressive, taking one to twelve hours, and is followed by rinsing in xylol and mounting.

Structures stained include those containing nucleic acids, various cytoplasmic particles, nerve cells and processes, corpora amylacea, lipofuscin, basement membranes, reticulin, collagen, cartilage matrix, mucin, fibrin, amyloid, muscle striations, pituitary and thyroid colloid, bacteria and epithelial brush borders.

Alternatively the sections, washed as above, or exposed to dry heat at $60-65^{\circ} \mathrm{C}$. for some hours, may be stained by burning saturated sudan black $B$ in 70 per cent alcohol over them ${ }^{1}$ six to ten times, washing in alcohol, clearing and mounting.

Here stained structures are those containing nucleic acids, red cells, erythroblast cytoplasm, eosinophil granules, muscle striations, cartilage matrix, mucin, lipofuscin, bacteria and thyroid colloid.

Continuous refluxing of tissues with ethanol-ether, methanol-chloroform and $n$-butanol-petroleum-ether

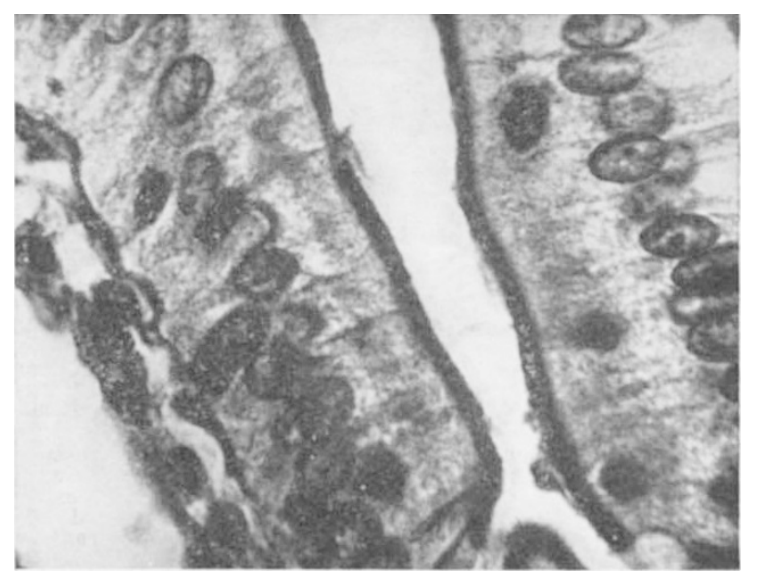

Intestinal epithelium of guinea pig; alcohol-fixed; washed $24 \mathrm{hr}$.; acetone - sudan black $6 \mathrm{hr}$. Showing staining of brush border, cytoplasmic granules, nuclei and basement membrane mixtures progressively reduces stainability, little being left after extraction for two weeks. The difficulty of disrupting some lipoprotein bonds by solvents alone is well known' ${ }^{2}$.

It is postulated that washing dissociates protein from laminated lipoproteins, allowing access to the stain $^{3}$.

This hypothesis is supported by the effect of mild peptic digestion $(0.2$ per cent pepsin in $0.05 \mathrm{~N}$ hydrochloric acid for $30 \mathrm{~min}$. at $37^{\circ} \mathrm{C}$.) and of soaps ${ }^{4}$ (i per cent sodium ricinoleate at $p \mathrm{H} 7$ for $1 \mathrm{hr}$. at $37^{\circ}$ C.), after either of which procedures sections stain intensely without further washing.

This evidence suggests that these methods stain lipids bound to protein, and possibly to carbohydrate and nucleic acids.

It is hoped to publish a full account of this and related work in due course.

\section{C. Berenbaum}

Department of Pathology,

Chase Farm Hospital,

Enfield, Middlesex. April 12.

1 Sheehan, H. C., and Whitwell, F., J. Path. Bact., 61, 269 (1949). ${ }^{2}$ Lovern, J. A., "The Mode of Occurrence of Fatty Acid Derivatives in Living Tissues" (H.M. Stationery Office, 1942).

${ }^{3}$ Grundland, I., and Bulliard, H., C.R. Acad. Sci., Paris, 207, 184 (1938).

4 Tayeau, F., C.R. Soc. Biol., Paris, 130, 1027 (1939).

\section{Extension of Range of the Angwantibo}

I wISH to correct a pardonable error in the review of "The Overloaded Ark" published in Nature of May 15, one in fact which I myself held until very recently. Arctocebus calabarensis is not found only in the forests of the British and French Cameroons. Two specimens of it have, a short time since, been taken in the Mamu River Forest Reserve, a patch of isolated remnant high forest situated some thirty miles east of Onitsha on the left bank of the Niger.

This is an interesting if not important discovery, since it extends the known range of this animal well beyond what is with some justification regarded as a faunal frontier precluding several animals of the main central African forest block from the West African block-the Cross River basin. The Angwantibo, which in its main habitat cannot truly be described as a "very rare" lemuroid, was certainly regarded as one of the chief of these; so, too, was Hylarnus batesi, which has likewise been captured well to the west of the Cameroons.

The high forests lying between the Cross River and the Niger, that is, in the densely populous Eastern Region of Nigeria, have been very largely destroyed, and it is thus difficult to determino precisely the limits of the central African block. In our present state of knowledge there appear, how. ever, to be indications from plants as well as animals that it is the somewhat insignificant Cross River rather than the Niger which forms the dividing line. To a scientific worker interested in animal distribution, investigation of the few remaining and little-known forest remnants of the Eastern Region of Nigeria, rather than the over-done Cameroons, would be well rewarding.

\section{R. Rosevear}

(Inspector-General of Forests)

ILagos,

Nigeria. 